\title{
THE FENNOSCANDIAN SHIELD WITHIN FENNOSCANDIA
}

\author{
JOAKIM DONNER
}

\begin{abstract}
DONNER, JOAKIM, 1996. The Fennoscandian Shield within Fennoscandia. Bull. Geol. Soc. Finland 68, Part 1, 99-103.
\end{abstract}

Keywords: nomenclature, Baltic Shield, Fennoscandian Shield, Precambrian, Fennoscandia.

Joakim Donner, Department of Geology, P.O. Box 11, FIN-00014 University of Helsinki, Finland

The Commission for the Geological Map of the World, CGMW, recommended in a resolution at its General Assembly in Kyoto, 24-28 August 1992, "that the name Baltic Shield should be replaced by the name Fennoscandian Shield". This was taken as an international acceptance of the use of this name (Vorma 1993), earlier recommended both by the unofficial Finnish working group of bedrock stratigraphy (Aro 1986, 1988) and by the Geological Survey of Finland (Marttila 1988), and mentioned as an alternative name already by Simonen (1980). The area of the shield with exposed Precambrian rocks, although largely covered by a sheet of Quaternary deposits, includes southern Norway, most of Sweden, Finland and in Russia the Kola peninsula in the north and areas south of the White Sea as far east as beyond Lake Onega. In general tectonic divisions of Europe it has been referred to as representing the Baltic Shield, bounded by the Caledonides (or Caledonian belt) in the northwest and in the east and south by Palaeozoic and younger strata of the East European
Platform (Russian Platform), as seen, for instance, on the maps presented by Holmes (1944, 1965). It is for this area (Fig. 1), geologically similar to the Canadian Shield, that the name Fennoscandian Shield should, according to the above-mentioned recommendation, be used.

The wish to replace the name Baltic Shield by the the name Fennoscandian Shield stems foremost from a linguistic confusion, as pointed out by Saltikoff (1992). The name Baltic Shield, as it has been used, refers to the Baltic (Sea), the English name corresponding to Mare balticum in Latin and la Baltique in French, as also to the name in Russian, Baltiiskoye morye. But in German the Baltic Sea, because it is in the east, is called die Ostsee and similarly in Swedish Östersjön. This has been translated into Finnish (Itämeri), whereas in Estonia the western situation of the Baltic is reflected in its name Läänemeri. But in spite of these names for the Baltic, the name for the Baltic Shield has been translated into Baltiska skölden in Swedish and Baltian kilpi in Finnish. This has led to the misconception that the name Baltic Shield refers 


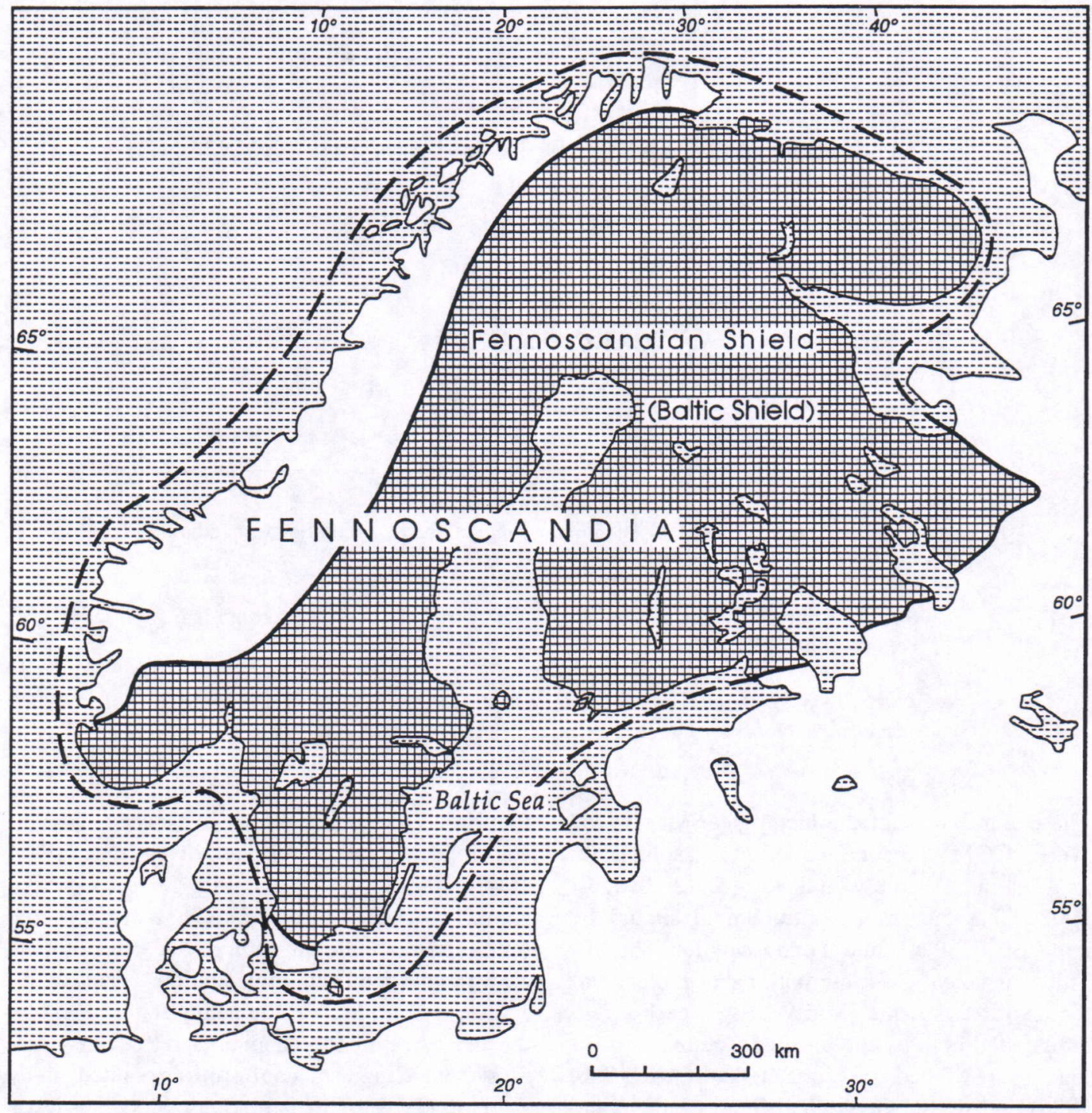

Figure 1. The Fennoscandian Shield (Baltic Shield) compared with the larger area of Fennoscandia, as defined by Ramsay.

to the area of the three states of Estonia, Latvia and Lithuania southeast of the Baltic, in the Early Middle Ages inhabited by the Baltic tribes and now referred to as the Baltic states, which all three lie outside the area of the exposed Precambrian shield. Seen against this background the wish to use the name Fennoscandian Shield is understandable, even if it in English is not necessarily better than the name Baltic Shield (Saltikoff 1992). If the latter name had originally been correctly translated from the name of the Baltic Sea into Swedish and Finnish the confusion with the names would have been avoided, as pointed out by Saltikoff. 


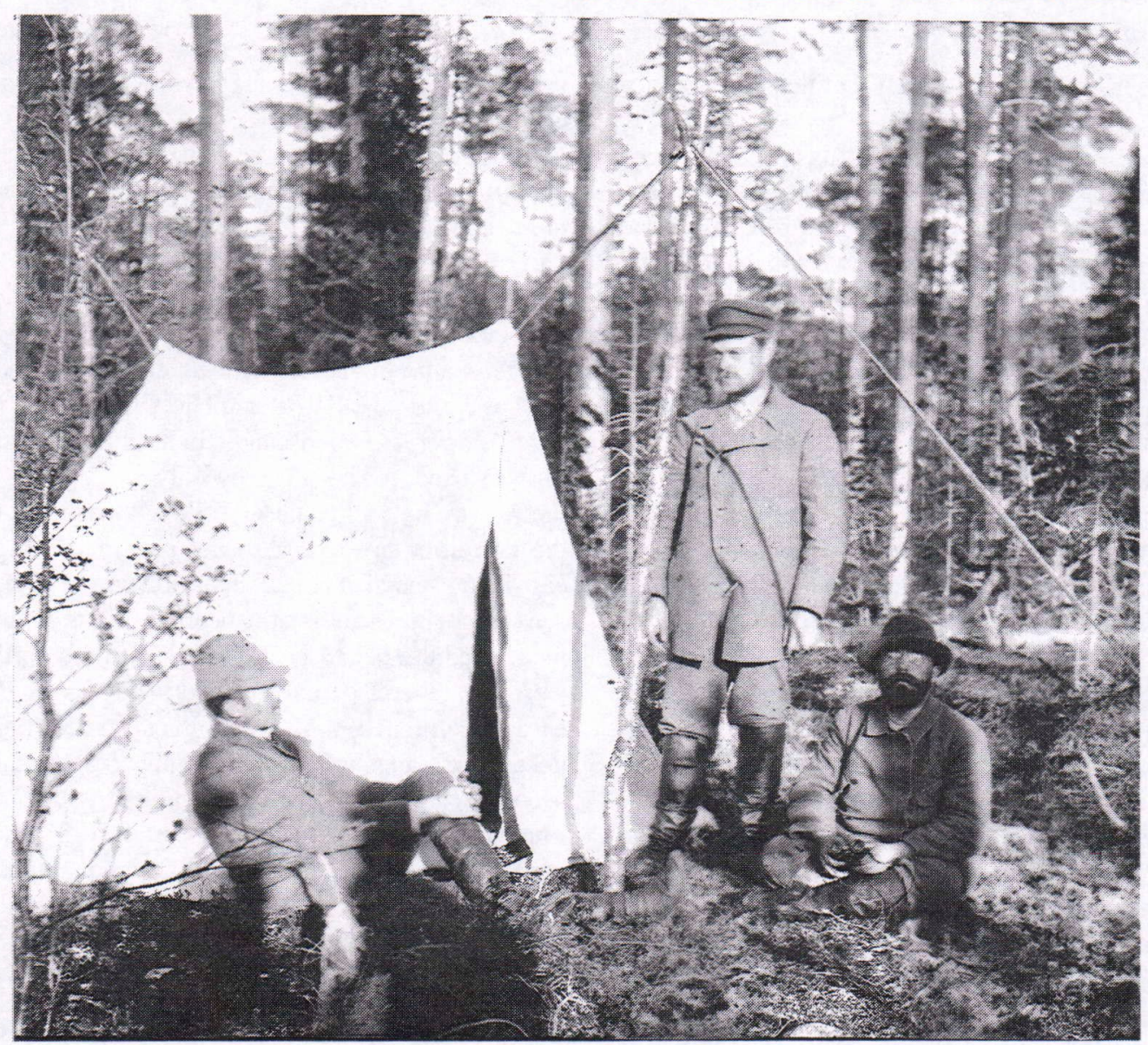

Figure 2. Wilhelm Ramsay (standing) at the age of 22 on the Kola peninsula expedition in 1887. Sitting on the left A.O. Kihlman (Kairamo) and on the right J. A. Palmén (courtesy Franciska Sundholm).

By accepting the use of the name Fennoscandian Shield instead of the name Baltic Shield another possibility of confusion is, however, introduced, because the area of the Fennoscandian Shield is different from the geographical area of Fennoscandia as originally suggested by Ramsay (1898) and later generally used. In his study of the Quaternary of the Kola peninsula, at the time when Finland was a Grand Duchy of the Russian Empire, Ramsay (Fig. 2) pointed out that the Kola peninsula, together with Norway, Sweden, Finland, Russian Karelia and the Onega area, including the northen part of the then province of Olonetz and the western part of that of Archangel, constitute a physico-geographical area sharply differing from its surrounding. As the southeastern boundary, however, is difficult to trace geologically, Kulikov (1995) suggested that the boundary here should be drawn on the basis of rivers, lakes, watersheds and other distinct natural features. This boundary suggested by Kulikov is outside that suggested by Ramsay, which has generally been used. In its western part Fennoscandia includes, according to the suggestion by Ramsay, the Caledonides of Norway as well as Scania in southernmost Sweden (Fig. 1). In this study of the Kola peninsula Ramsay (1898), in introducing the name Fennoscandia, stressed the similarities of the Quaternary features on the Kola peninsula with those in other parts of Fennoscandia, but as a concept the name, 
as seen, refers to a clearly defined geographical area.

The reason why Ramsay suggested the name Fennoscandia was that there was not a suitable name for this area; northern Europe comprises a bigger area and, furthermore, what is interesting to note here, the name Baltic Shield excludes the Palaeozoic mountains and Scania. Fennoscandia is, as pointed out by Ramsay, also identical with the Scandinavian-Finnish biogeographical area used by botanists and zoologists, as well as an area for long foremost inhabited by Scandinavian and Finnish people. Ramsay's argument was in keeping with the national romantic movement, Karelianism, that affected many of the Finnish painters at the end of the last century (Smith 1970).

In spite of the clear definition of the name Fennoscandia by Ramsay in his original paper (see also Ramsay 1931), Sederholm (1932) unfortunately misleadingly, by writing about the geology of Fennoscandia, stated, without giving any references, that "it was earlier often called the Baltic Shield, but Fennoscandia, proposed by Wilhelm Ramsay, seems far the better name". This statement was unfortunately later quoted in favour of the use of the name Fennoscandian Shield instead of the name Baltic Shield (Marttila 1988). A certain confusion between the name Fennoscandia and the Baltic Shield is also reflected in the discussion of the geological and morphological features by Tanner (1938) who, however, did not quote the original paper by Ramsay (1898) in which Fennoscandia was defined.

From the discussion above it follows that the area of the Fennoscandian Shield, the name recommended instead of the name Baltic Shield, is part of the area defined as Fennoscandia (Fig. 1). In general geological texts published outside Finland this distinction seems to be accepted. In Sweden the name Fennoscandian Shield was already used by Lundqvist (1976) and Hjort and Sundquist (1979), whereas Fennoscandia in its correct meaning was used, for instance, by Nilsson (1983) and in Norway by Holtedahl (1953), who referred to the Precambrian rocks as being part of the large east-Fennoscandian shield area. In Denmark Hansen (1965), in discussing the bedrock of Bornholm, mentioned the Fennoscandian Shield in the northwest. In general geological textbooks, as in the earlier mentioned book by Holmes (1965), Fennoscandia is mentioned as a geographical area, in accordance with the original definition by Ramsay. There has thus been an awareness of the difference between the Fennoscandian Shield and Fennoscandia for some time, well before the use of the name Fennoscandian Shield was recommended in 1992.

ACKNOWLEDGEMENTS: The author is grateful to Professor Franciska Sundholm for providing the photograph of Wilhelm Ramsay for publication, and to Ms Tuija Jantunen, Phil. lic., for drawing the map. 


\section{REFERENCES}

Aro, K., 1986. Kallioperästratigrafian työryhmä perustettu. Geologi 1986 (6), 149.

Aro, K., 1988. Kallioperästratigrafian työryhmä tiedottaa. Geologi 1988 (1), 15.

Hjort, C. \& Sundquist, B., 1979. Geologi och miljö. Stockholm: Natur och Kultur, 160 p.

Holmes, A., 1944. Principles of physical geology. Nelson, 532 p.

Holmes, A., 1965. Principles of physical geology. New and fully revised edition. Nelson, $1288 \mathrm{p}$.

Holtedahl, O., 1953. Norges geologi I. Norges Geologiske Undersøkelse 164, 583 p.

Kulikov, V.S., 1995. Where is the southern boundary of Fennoscandia? Bulletin of the Geological Society of Finland 67 (2), 73-75.

Lundqvist, J., 1976. Geologin - från teori till tillämpning. Kristianstad: LTs förlag, 224 p.

Marttila, E., 1988. Editor's notes to the English edition. In Archaean geology of the Fennoscandian Shield, ed. E. Marttila, p. 2. Geological Survey of Finland, Special Paper 4, 228 p.
Nilsson, T., 1983. The Pleistocene: Geology and life in the Quaternary ice age. Dordrecht: Reidel, 651 p.

Ramsay, W., 1898. Über die Geologische Entwicklung der Halbinsel Kola in der Quartärzeit. Fennia 16 (1), $151 \mathrm{p}$.

Ramsay, W., 1931. Geologiens grunder II. Helsingfors, Holger Schildts Förlag, 481 p.

Saltikoff, B., 1992. Baltiasta. Geologi 1992 (9-10), 176.

Sederholm, J.J., 1932. On the geology of Fennoscandia with special reference to the Pre-Cambrian. Explanatory notes to accompany a general map on Fennoscandia. Fennia 55 (2), 30 p.

Simonen, A., 1980. The Precambrian in Finland. Geological Survey of Finland Bulletin 304, 58 p.

Smith, J.B., 1970. Modern Finnish painting and graphic art. Weidenfeld and Nicolson, 62 p.

Tanner, V., 1938. Die Oberflächengestaltung Finnlands. Bidrag till kännedom af Finlands natur och folk, Finska Vetenskaps-Societeten, 86, 762 p.

Vorma, A., 1993. Vielä kerran Baltiasta. Geologi 1993 (1), 25. 